\title{
Journal of Anglican Studies: Change of Editor
}

Graeme L. Blackman

Journal of Anglican Studies Trust

Email: Graeme.blackman@gmail.com

The Trustees of the Journal of Anglican Studies are pleased to announce the appointment of Professor Peter Sherlock as the new Editor of the Journal with effect from 1 July 2020.

Our present Editor Professor Andrew McGowan, of Yale University, has decided to lay down his responsibilities as Editor in 2020. Professor McGowan took up the Editorship in 2013. He has contributed greatly to the development of the Journal most especially through the introduction of Scholar One online manuscript management software. This has meant that all manuscripts are handled online, in collaboration with Cambridge University Press, right up to the point of digital publication on the CUP portal.

The Trustees wish to express their great appreciation for the contribution that Andrew has made to the Journal and thus to scholarly conversation on all things related to Anglicanism. We are also very grateful for the support he has received from Yale University and the Berkeley Divinity School at Yale, of which he is the President. We are pleased to announce that Professor McGowan will continue his association with the JAS as a Consulting Editor and also facilitate the induction of the new Editor over a generous transition period.

Professor Sherlock is the Vice-Chancellor of the University of Divinity. He brings to the role of Editor outstanding academic qualifications and a strong track record in Anglican studies. He holds a doctorate in History from the University of Oxford where he was a Commonwealth Scholar. He was an Australian Research Council Postdoctoral Fellow in History at the University of Melbourne and has held Visiting Fellowships at the Folger Shakespeare Library in Washington DC and in the Department of Theology at Durham University. He has published widely on Anglicanism as well as broader historical and religious themes, and he has developed and taught units on Anglican Studies through Trinity College Theological School in Melbourne.

He has significant direct involvement in Anglican governance and practice as a member of the General Synod of the Anglican Church of Australia and of the Synod of the Diocese of Melbourne, and as a Lay Clerk in the Choir of St Paul's Cathedral, Melbourne. He will fulfil his new editorial responsibilities in conjunction with his current role as Vice-Chancellor with the encouragement of the Council of the University of Divinity. The Trustees are very grateful to the University for this support.

Cite this article: Blackman, G.L. (2020). Journal of Anglican Studies: Change of Editor. Journal of Anglican Studies 18, 1. https://doi.org/10.1017/S1740355320000297 